\title{
Inovasi Layanan Aplikasi E Samsat Dalam Pembayaran Pajak Kendaraan Bermotor Di Provinsi Riau
}

\author{
${ }^{1}$ Evi Zubaidah, ${ }^{2}$ Ema Fitri Lubis \\ ${ }^{12}$ Fakultas Ilmu Sosial dan Ilmu Politik Universitas Islam Riau \\ e-mail : evizubaidah@soc.uir.ac.id
}

\begin{abstract}
Abstrak
Banyaknya pelayanan pembayaran pajak di kantor samsat di provinsi Riau maka masyarakat membutuhkan inovasi layanan yang lebih mudah dalam mengakses pelayanan pembayaran pajak kenderaan bermotor. Sehingga munculah aplikasi layanan E-samsat merupakan salah satu aplikasi online bertujuan untuk melayani dan mempermudah masyarakat dalam pembayaran Pajak Kendaraan Bermotor. Tujuan dari penelitian ini adalah untuk mendeskripsikan secara mendalam inovasi layanan aplikasi E-samsat dalam pembayaran pajak kenderaan bermotor di Provinsi Riau sebagai wujud pelayanan prima di kantor E-samsat Provinsi Riau. Metode penelitian yang digunakan dalam penelitian ini adalah metode deskriptif kualitatif dengan teknik pengumpulan data melalui wawancara, observasi dan dokumentasi. Pengumpulan data, reduksi data, dan penarikan kesimpulan yang dilakukan pada teknik analisis data. Hasil penelitian ini menunjukkan bahwa dari beberapa atribut inovasi pada inovasi layanan e-samsat yakni Relative Advantage (keuntungan relatif) yaitu kemudahan masyarakat dalam pengurusan pembayan pajak kenderaan bermotor (PKB). Compatibility (kesesuaian) dimana inovasi layanan e-samsat bagi masyarakat kota Pekanbaru sudah sesuai dengan kondisi perkembangan teknologi saat ini. Complexity (kerumitan) dimana inovasi layanan e-samsat dirasa tidak rumit dalam proses pelaksanannya. Kemudian Triability (kemungkinan dicoba) masyarakat Kota Pekanbaru yang merespon positif dengan adanya layanan e-samsat. Selanjutnya dari Observability (kemudahan diamati) dengan prosedur pelayanan yang cukup simple secara elektronik.
\end{abstract}

Kata kunci : Inovasi, Pelayanan, E-samsat Provinsi Riau

\begin{abstract}
With the number of tax payment services at the Samsat office in Riau province, people need service innovations that are easier to access motorized vehicle tax payment services. So that the E-Samsat service application appears, which is an online application that aims to serve and facilitate the public in paying Motor Vehicle Taxes. The purpose of this study is to describe in depth the innovation of the E-Samsat application service in motor vehicle tax payments in Riau Province as a form of excellent service at the E-Samsat office of Riau Province. The research method used in this research is descriptive qualitative method with data collection techniques through interviews, observation and documentation. Data collection, data reduction, and drawing conclusions made on data analysis techniques. The results of this study indicate that some of the attributes of innovation in e-Samsat service innovation are Relative Advantage (relative advantage), namely the ease with which people can handle motorized vehicle tax payment (PKB). Compatibility (suitability) where the e-Samsat service innovation for the people of Pekanbaru city is in accordance with the current conditions of technological development. Complexity where the e-Samsat service innovation is not complicated in the implementation process. Then the Triability (possibly being tried) of the people of Pekanbaru City responded positively to the e-Samsat service. Furthermore, from Observability (ease of observation) with a fairly simple service procedure electronically.
\end{abstract}

Keywords: Innovation, Service, E- Samsat Riau Province 


\section{PENDAHULUAN}

Pembangunan di Indonesia, setidaknya memiliki tiga masalah; pertama mengenai birokrasi yang masih gemuk, lamban, dan belum mampu memberikan pelayanan prima pada masyarakat Dan investor. Kedua adalah tentang korupsi, dimana masih banyak penyelenggara negara yang menyalahgunakan pengelolaan keuangan negara. Ketiga; terkait masalah infrastruktur yang belum memadai, serta kurangnya anggaran negara untuk pembangunan dan pemeliharaannya. Berangkat dari tiga kondisi itu maka program percepatan reformasi birokrasi sangatlah diperlukan guna menciptakan birokrasi bersih dari korupsi kolusi dan nepotisme, melayani, serta berkompeten terhadap tugas dan tanggung jawab yang diemban.

Pelayanan publik kini telah menjadi isu sentral dalam pembangunan di Indonesia. Perkembangannya pelayanan publik memang selalu aktual untuk diperbincangkan. Pada dasarnya memang manusia membutuhkan pelayanan, konsep pelayanan akan selalu berada pada kehidupan setiap manusia. Penyelenggaraan pelayanan publik saat ini sesuai dengan paradigma pelayanan publik yang berkembang yakni New Public Service (NPS). Paradigma New Public Service (NPS) memandang publik sebagai citizen atau warga negara yang mempunyai hak dan kewajiban publik yang sama. Tidak hanya sebagai customer yang dilihat dari kemampuannya membeli atau membayar produk atau jasa. Citizen adalah penerima dan pengguna jasa publik yang disediakan pemerintah dan sekaligus juga subyek dari berbagai kewajiban publik seperti mematuhi peraturan perundang-undangan, membayar pajak, membela Negara, dan sebagainya. Yuliani, S. (2007). Mewujudkan Birokrasi Y ang Pro-Citizen. Yogyakarta: Jurnal FISIP UNS, 3(1).

Dalam Ratmito dan Atik (2012), ukuran keberhasilan penyelenggaraan pelayanan ditentukan oleh tingkat kepuasan penerima pelayanan. Kepuasan penerima pelayanan dicapai apabila penerima pelayanan sesuai dengan yang dibutuhkan dan diharapkan. Terselenggaranya pelayanan publik yang baik, tergantung dari kondisi birokrasi disuatu negara. Kondisi birokrasi memberikan iklim tersendiri bagi terselenggaranya pelayanan publik yang optimal. Pelayanan publik yang optimal belum tentu dapat direalisasikan di Indonesia. Kondisi pelayanan publik di Indonesia masih sangat rendah. Demikian salah satu kesimpulan Bank dunia yang dilaporkan World Develoment Report 2004 dan hasil penelitian Governance and Desentralization Survey (GDS) 2002. (Agus Dwiyanto \& Bevaola Kusumasari 2003 : No II)

Inovasi disektor publik saat ini menjadi sebuah keharusan untuk membuat ketersediaan layanan yang semakin mudah, murah, terjangkau, dan merata (Suwarno, 2008 : 32-33). Di Indonesia, setelah adanya otonomi daerah, perubahan sistem pemerintahan ini juga diiringi tuntutan perubahan kualitas pelayanan yang diharapkan masyarakat. Penyediaan pelayanan publik yang berkualitas merupakan kewajiban yang harus dilakukan oleh setiap penyelenggara. Konsepsi otonomi daerah sebagaimana diatur dalam UU No 32 Tahun 2004 telah memberikan kewenangan dan keleluasan pemerintah daerah untuk dapat menyelenggarakan pelayanan publik yang berkualitas. Seiring dengan lahirnya otonomi daerah tersebut diharapkan setiap daerah berani mengambil inisiatif, mampu membuat terobosan baru atau melakukan inovasi untuk memajukan daerahnya (Ratminto, 2010:188). Keanekaragaman dalam pelayanan publik mendorong untuk terciptanya pelayanan inovatif. Pelayanan inovatif, dapat dikaitkan dengan inovasi pelayanan publik. Dimana inovasi pelayanan publik, merupakan hal yang dapat diwujudkan dalam memberikan pelayanan kepada masyarakat. Inovasi, menurut Rogers adalah "an innovation is an idea, practice, or object that is perceived sebuah ide, praktik, atau objek yang dianggap baru oleh individu satu unit adopsi lainnya). (Rogers Everret $2003: 12$ )

Inovasi digunakan sebagai tuntutan akuntabilitas, transparansi dan berbagai prinsip good governance, yang menggiring organisasi publik yang berkinerja lebih tinggi. ( Jasfar Farida 2012 : 23). Salah satu inovasi pelayanan publik yang dilaksanakan pada saat ini adalah layanan aplikasi e samsat dalam pembayaran pajak kendaraan bermotor. Pelayanan publik merupakan unsur yang sangat penting dalam penyelenggaraan pemerintahan karena menyangkut aspek kehidupan yang sangat luas. Birokrasi pemerintah tidak lagi menampilkan sosok sebagai penguasa tetapi sebagai pelayan masyarakat. Semua bentuk kegiatan 
pemerintah dan pembangunan harus dikelola secara transparan dan dapat dipertanggung jawabkan. Hal ini membuat banyak organisasi termasuk pelayanan publik melakukan inovasi dalam memberikan pelayanannya. Pelayanan yang inovatif dan menguntungkan masyarakat sebagai pengguna jasa akan lebih dinikmati oleh masyarakat.

E-samsat merupakan salah satu aplikasi online bertujuan untuk melayani dan mempermudah masyarakat dalam pembayaran Pajak Kendaraan Bermotor. Jika terdahulu pemilik kendaraan harus datang ke kantor Samsat (Sistem Administrasi Manunggal Satu Atas) untuk mengurus perpanjangan STNK (Surat Tanda Nomor Kendaraan) dengan waktu yang lama, kini prosedur tersebut sudah bisa dilakukan secara online melalui e samsat, Terobosan ini tentu sangat memudahkan masyarakat yang memiliki kesibukan masing- masing. Dari penerapan layanan pembayaran pajak kenderaan bermotor melalui e-samsat.

\section{METODE}

Metode penelitian yang digunakan dalam penelitian ini adalah metode deskriptif kualitatif dengan teknik pengumpulan data melalui wawancara, observasi dan dokumentasi. Peneliti telah melakukan survey awal terlebih dahulu ke Badan Pendapatan Daerah Provinsi Riau selaku pengelola data tentang pelaksanaan pembayaran pajak kendaraan bermotor (PKB) yang menggunakan layanan e-samsat, dan meperoleh data masyarakat kota pekanbaru yang melakukan pembayaran PKB melalui e-samsat. Selanjutnya diadakan wawancara terhadap key informan, dilakukan pengumpulan data, reduksi data, dan penarikan kesimpulan yang dilakukan pada teknik analisis data. Informan yang diperoleh dari key informan setelah penelitian dilakukan dapat dilihat pada tabel berikut ini :

Tabel 1. Informan Penelitian

\begin{tabular}{llllc}
\hline No & \multicolumn{1}{c}{ Fungsi } & \multicolumn{1}{c}{ Identitas } & Jumlah \\
\hline \multirow{2}{*}{1} & Key informan & $\begin{array}{l}\text { Koordinator Unit Pelayanan Pengelolaan } \\
\text { Pendapatan E-Samsat }\end{array}$ & 1 \\
\cline { 3 - 5 } & $\begin{array}{l}\text { Staff Koordinator Unit Pelayanan } \\
\text { Pengelolaan Pendapatan E-Samsat }\end{array}$ & 1 \\
\hline \multirow{2}{*}{2} & Informan & $\begin{array}{l}\text { Masyarakat Kota Pekanbaru yang } \\
\text { melakukan pembayaran } \\
\text { menggunakan layanan e-samsat }\end{array}$ & PKB & 5 \\
\hline
\end{tabular}




\section{HASIL DAN PEMBAHASAN}

\section{Inovasi Layanan Aplikasi E Samsat Dalam Pembayaran Pajak Kendaraan Bermotor Di Provinsi Riau}

Pesatnya kemajuan teknologi dan informasi, memaksa penyelenggara pelayanan publik untuk terus melakukan inovasi dalam rangka menyediakan kebutuhan akan tuntutan masyarakat tersebut. Adapun inovasi yang dilakukan oleh Kantor Samsat di Provinsi Riau adalah pembayaran pajak dengan sistem elektronik yang disebut sebagai E-samsat, untuk mengetahui inovasi tersebut peneliti menggunakan lima atribut inovasi menurut Rogers yaitu: Rogers (1983) yaitu: Keunggulan Relatif (relative advantage), Kesesuaian (compatibility), Kerumitan (complexity), Kemampuan diuji cobakan (trialability), dan Kemampuan diamati (observability).

1. Relative Advantage (keuntungan relatif)

Keuntungan bagi masyarakat khususnya untuk inovasi layanan e-samsat adalah dengan kemudaha masyarakat membayar pajak kendaraan bermotor, yang mana bisa dilakukan dengan online tanpa harus melakukan birokrasi yang rumit. Dari menggunakan E- samsat pendapatan daerah meningkat.

2. Compatibility (kesesuaian)

Ditinjau dari segi kesesuain inovasi layanan e-samsat bagi masyarakat kota Pekanbaru sudah sesuai dengan kondisi perkembangan teknologi yang maju seperti saat ini, karena dapat memproses pembayaran pajak kendaraan bermotor dapat dilakukan sewaktu-waktu dengan mesin ATM tanpa harus dibatasi oleh waktu.

3. Complexity (kerumitan)

Ditinjau dari aspek kerumitan inovasi layanan e-samsat dirasa tidak rumit dalam proses pelaksanannya. atribut inovasi complexity atau kerumitan terkait dengan mekanisme, tata cara atau prosedur pelayanan dalam pelaksanaannya tidak terdapat perbedaan dengan layanan elektronik lainnya. Terkait dengan mekanisme, tata cara atau prosedur pada layanan e-samsat sudah cukup baik. Dimana mekanisme, tata cara atau prosedur yang ada dibuat memudahkan masyarakat dalam melakukan pelayanan pembayaran PKB, dimana masyarakat melakukan pembayaran melalui mesin ATM di Bank Riau Kepri, kemudian bukti pembayaran melalui ATM tersebut digunakan untuk pencetakan SKPD dan Pengesahan STNK ke kantor samsat terdekat.

\section{Triability (kemungkinan dicoba)}

Dari segi atribut kemungkinan dicoba berkenaan dengan sosialisasi yang dilakukan oleh Badan Pendapatan Daerah Provinsi Riau terkait layanan e-samsat, adapun sosialisasi yang dilakukan yakni melalui media massa maupun media elektronik seperti : radio, televisi dan media cetak. Sehingga sudah banyak diketahui oleh masyarakat Kota Pekanbaru yang merespon positif dengan adanya layanan e-samsat tersebut. Walapun sebagian masyarakat masih kurang percaya menggunakan layanan e-samsat itu menjadi lebih efisien.

5. Observability (kemudahan diamati)

Dalam inovasi layanan e-samsat di Provinsi Riau dari segi kemudahan diamati yakni menyangkut dengan adanya kehadiran layanan e-samsat khususnya masyarakat kota Pekanbaru dapat dengan mudah dijangkau oleh masyarakat. Mudah diamati dengan prosedur pelayanan yang cukup simple secara elektronik, karna dalam proses pelayanan akan terbebas dari deskriminasi yang menyebabkan terjadinya praktek pungli 


\section{KESIMPULAN}

E-samsat Provinsi Riau merupakan bentuk peningkatan kualitas pelayanan publik secara berkelanjutan yang terpadu dan terintegrasi antara pelayanan pemerintah pusat dan pemerintah daerah dalam satu gedung pelayanan, sehingga masyarakat kota pekanbaru lebih mudah dalam mengakses pelayanan tanpa harus berbolak-balik untuk mengurus pelayanan yang satu ke yang lain. Penelitian ini menggunakan teori Everett M. Rogers (2003) dalam Suwarno (2008:17), Dalam penerapannya inovasi memiliki atribut yang melekat didalam inovasi tersebut. Atribut inovasi yang dimaksud adalah sebagai berikut Relative Advantage (keuntungan relatif), Compatibility (kesesuaian), Complexity (kerumitan), Triability (kemungkinan dicoba), Observability (kemudahan diamati),. Hasil penelitian ini menunjukkan bahwa inovasi layanan E-samsat di Provinsi Riau dari segi keuntungan yaitu kemudahan masyarakat dalampengurusan pembayan pajak kenderaan bermotor (PKB). Dari segi kesesuaian inovasi layanan esamsat bagi masyarakat kota Pekanbaru sudah sesuai dengan kondisi perkembangan teknologi saat ini. Segi kerumitan diperoleh hasilnya adalah inovasi layanan e-samsat dirasa tidak rumit dalam proses pelaksanannya. Kemudian segi kemungkinan dicoba masyarakat Kota Pekanbaru yang merespon positif dengan adanya layanan e-samsat. Selanjutnya dari segi indikator kemudahan diamati dengan prosedur pelayanan yang cukup simple secara elektronik.

\section{SARAN}

Diharapkan dengan adanya Inovasi Layanan E-samsat di Provinsi Riau ini dalam memberi kemudahan pelayanan yang didapatkan masyarakat terealisasi dengan baik. Bagi pemerintah diharapkan untuk terus meninjau keberlangsungan pelaksanaan layanan E-samsat di Provinsi Riau apabila ada penyimpangan hendaknya segera ditindaklanjuti. Bagi pegawai kantor samsat Provinsi Riau diharapkan memberikan pelayanan sebaik mungkin kepada masyarakat sesuai dengan peraturan yang ditetapkan. Selain itu, masyarakat juga berperan penting dalam pelaksanaan E-samsat dan diharapkan taat aturan. 


\section{DAFTAR PUSTAKA}

[1] Dwiyanto, A., \& Kusumasari, B. Optimalisasi Pelayanan Publik: Perspektif David Osborne Dan Ted Gaebler Oleh: Ahmad Zaenal Fanani, Shi., M. Si (Hakim Pa Martapura).

[2] Kurniawan, Agung. 2005. Transformasi Pelayanan Publik. Yogyakarta: Pembaharuan

[3] Ratminto \& Atik Septi Winarsih. 2010 Manajemen Pelayanan: Pengembangan Model Konseptual, Penerapan Citizen's Charter Dan Standar Pelayanan Minimal, Yogyakarat: Pustaka Pelajar.

[4] Sinambela, Lijan P. Dkk (2006). Reformasi Pelayanan Publik: Teori, Kebijakan, Dan Implementasi. Jakarta: Bumi Aksara

[5] Suwarno, Yogi. (2008). Inovasi Di Sektor Publik. Stia-Lan, Jakarta.

[6] Thenint, Hugo Ll \& A. 2010. Mini Study 10 Innovation In The Public Sector. Manchester. Global Review Of Inovation Inteligence And Policy Studies: Inno Gripe

[7] Winarsih, S. Atik \& Ratminto. 2012. Manajemen Pelayanan. Yogyakarta: Pustaka Pelajar.

[8] Yuliani, S. (2007). Mewujudkan Birokrasi Yang Pro-Citizen. Jurnal Ilmu Administrasi Fisip Uns, 3(1) 